\title{
Viral Myocarditis: Physiopathology and Diagnosis
}

\author{
Andréoletti Laurent \\ Head of the clinical and molecular Virology Unit, \\ University medical centre and EA research team at the \\ Medicine Faculty of Reims \\ France
}

\section{Introduction}

In Europe and the USA, viral aetiologies largely prevail over other causes of myocarditis as previously indicated by recent data demonstrating the molecular detection of cardiotropic viruses in human cardiac biopsy samples (Kühl et al., 2005a). Clinical presentations of the myocarditis range from non-specific systemic symptoms (fever, myalgias, palpitations, or exertional dyspnea) to fulminant hemodynamic collapse (5 to 10 cases per million inhabitants and per year) and sudden cardiac death (Feldman \& McNamara, 2000; Magnani \& Dec, 2006).

Acute myocarditis remains a complex and challenging diagnosis in cardiology (Magnani \& Dec, 2006). This cardiomyopathy is defined histologically by the Dallas criteria as an "inflammation of the myocardium" associated with necrosis and an absence of ischaemia (Aretz et al., 1987; Cooper, 2009; Dennert et al., 2008; Felmann \& McNamara, 2000). The use of the Dallas criteria in the diagnosis of myocarditis is associated with poor sensitivity and specificity, mainly because of the sampling error related to the often focal distribution of the specific histological lesions in cardiac tissue and because of the variability in pathological interpretation (Baughman, 2006; Mahrholdt et al., 2004). Moreover, the Dallas classification does not consider local quantification and differentiation of inflammatory cells and does not take into account viral infection and autoimmune regulation in cardiac tissues (Dennert et al., 2008). To improve the histological diagnosis, additional virological and immunological evaluations of cardiac tissues are required using immunohistochemical and PCR techniques, which allow identification and quantification of inflammatory cells and viral infection markers (Dennert et al., 2008). The diagnostic gold standard is endomyocardial biopsy with the histological Dallas criteria in association with new immunohistochemical and viral PCR analyses of cardiac tissues (Cooper et al., 2007). This new diagnostic approach can lead to better identification of the aetiological cause of the myocarditis and can improve the clinical management of viral myocarditis. This chapter chronicles the advances in understanding the physiopathology of viral acute and chronic myocarditis and in the development of new molecular techniques for an accurate and valuable virological diagnosis. 


\section{Human viral cardiac infection: proofs of concept and clinical relevance}

Common human pathogenic DNA or RNA viruses can be responsible for acute or chronic endomyocardial tissue infection (Andréoletti et al., 1995; 2009; Kühl et al., 2005a). The detection of components (DNA or RNA genomes or viral proteins) of these viral agents by molecular techniques such as polymerase chain reaction (PCR) and/or immunohistochemical techniques demonstrating the viral protein expression in the cytoplasm of myocytes, was associated with an inflammation of the myocardium (acute myocarditis), arrhythmias, loss of contractility (Andréoletti et al., 2009; Cooper, 2009; Dennert et al., 2008). Moreover in serial of human cases, the presence of viral persistence was evidenced in the myocardium and associated with a left ventricular systolic dysfunction in relation to a reduction in the contractile function of the myocytes (Andréoletti et al., 2000; Badorff et al., 2001). Additional proofs of concept were that: (I) a longitudinal clinical investigation showed that the type of virus, the clinical presentation and the type of histological damage appeared to be related to the clinical course of the cardiac disease; (II) longitudinal clinical studies indicated that the immune clearance of the virus during or after the acute phase was correlated with an improvement of the left ventricular ejection fraction [LVEF] (Kühl et al. 2005b); (III) acute and chronic myocarditis as well as dilated cardiomyopathy (DCM) were reproduced in immunocompetent animal models following experimental viral infections (Andréoletti et al., 1997; Huber, 1993; Matsumori \& Kawai, 1982). Altogether these clinical and experimental data supported the pathophysiological role of several human viruses in the genesis and the evolution of myocarditis and the DCM. Although up to $90 \%$ of people will be infected by at least one or more of these viruses in their life without getting their heart injured with associated clinical signs, only a few number will develop clinical symptoms. Therefore, it is highly suspected that a certain genetic background either related to immune alterations or to an improved susceptibility to viral cardiac infection (viral receptor or co-receptors polymorphisms) may be a prerequisite to develop clinical symptoms of myocarditis and/or progression to DCM following virus heart tissue infection. In addition, it has been shown that dystrophin mutations may make easier the development and progression of myocarditis and cardiac failure during coxsackievirus B3 infection, whereas dystrophin and/or sarcoglycan disruption by viral proteases account for myocardial injury (Andréoletti et al., 2007; Badorff et al., 2001; Lee et al., 2000). Human genetic studies of patients with myocarditis are rare and only 2 reports show an association between myocarditis and genetic factors such as HLA-DQ locus and CD45 polymorphism (Yajima \& Knowlton, 2009). Future clinical investigations should therefore focus on the understanding of the underlying genetic susceptibility and related immune responses that explain why some patients are susceptible to develop clinical symptoms of acute myocarditis following viral infection, whereas other subjects clinically recover or progress to an 'idiopathic' DCM after the initial phase of the viral cardiac infection.

\section{The pathophysiological mechanisms of viral myocarditis}

The current understanding of the immunopathologcial phases of myocarditis derives largely from enterovirus-induced myocarditis in murine models (Andréoletti et al, 1997; Cooper et al., 2007; Liu \& Mason, 2001; Yajima \& Knowlton, 2009). During the enterovirus (virus Coxsackie B) natural course of infection, the data obtained from experimental murine 
models allowed the identification of three distinct pathophysiological phases defined as acute, sub-acute and chronic myocarditis (Cooper, 2003; Feldman \& McNamara, 2000; Yajima \& Knowlton, 2009) (Figure 1).

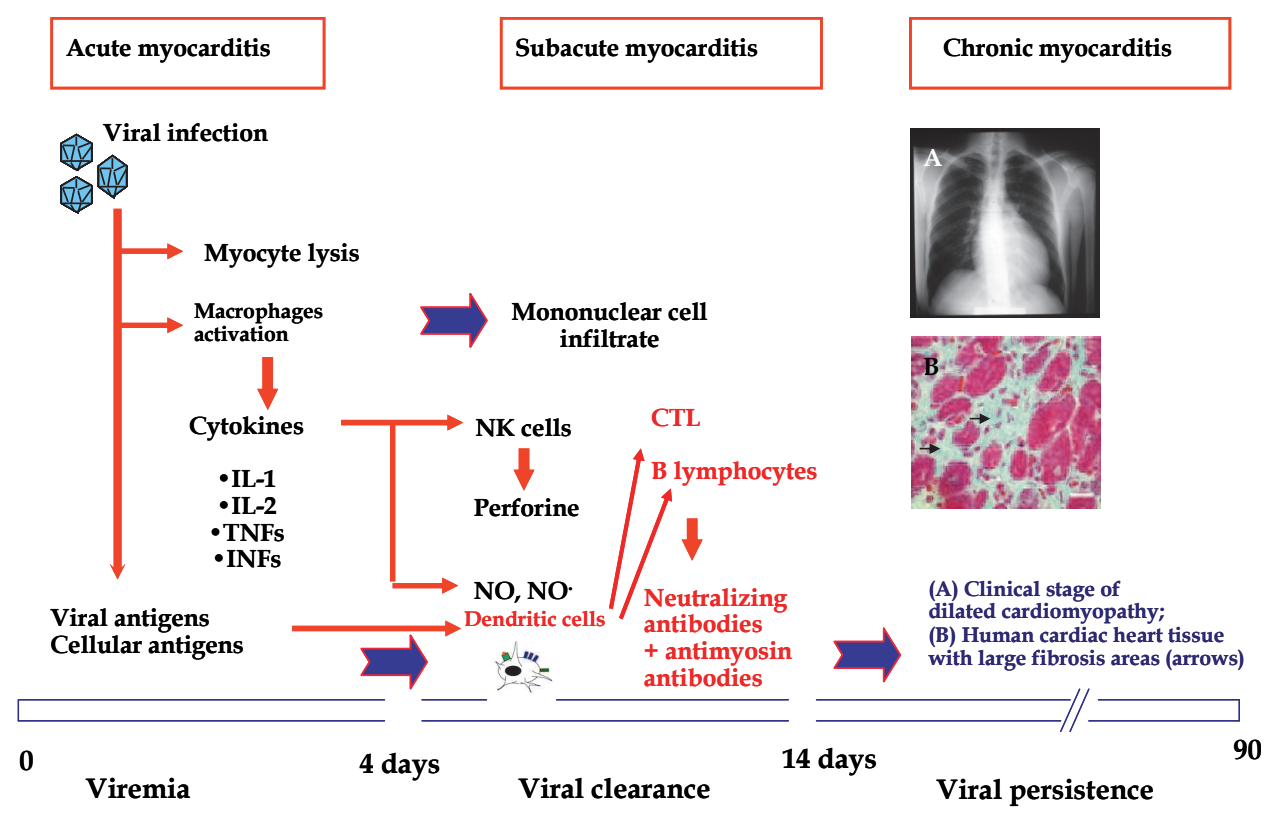

Fig. 1. Immunopathological phases of viral myocarditis.

\subsection{Acute myocarditis during the initial Virus invasion}

During the period of active viremia, cardiotropic RNA or DNA viruses interact with specific vascular endothelial cell receptors before to be translated in the endomyocardial target cells to produce viral proteins (Huber, 1993; Li et al., 2000) (Table 1). Mechanisms of viral entry into the host cell remains crucial and are of major interest because each of them is putative target for novel therapeutics. Before to interact specifically with the virus, expression of levels of the virus receptors for CVB3, PVB19, HVV6 (CAR/DAF, P-Antigen/ Alpha5-beta1 integrin and $\mathrm{CD} 46$, respectively) on endovascular endothelial cells of coronary vessels modulate the diffusion of these viral agents into the vessels and their subsequent translation into the endomyocardial target cells (Khül et al., 2005a; Yajima \& Knowlton, 2009). Some inflammatory mechanisms as a primary persistent infection by HHV6 or PVB19 may modulate cell membrane receptors and /or immune suppression and preventing virus clearance; altogether these mechanisms could facilitate an endomyocardial super infection by a second viral agent as described in $27 \%$ of virus positive DCM patients (Khül et al., 2005a) (Table 1). 


\begin{tabular}{|c|c|c|c|c|}
\hline $\begin{array}{l}\text { Common } \\
\text { cardiotropic } \\
\text { Viruses }\end{array}$ & $\begin{array}{l}\text { Detection } \\
\text { Methods }\end{array}$ & $\begin{array}{c}\text { Cardiovascular } \\
\text { tissular } \\
\text { Localization }\end{array}$ & $\begin{array}{l}\text { Cellular Receptor / } \\
\text { Coreceptor Involved }\end{array}$ & References \\
\hline Adenovirus & EM & $\begin{array}{l}\text { Cardiomyocytes, } \\
\text { fibroblasts, } \\
\text { endothelial cells }\end{array}$ & $\begin{array}{l}\text { CAR / Integrins } \\
(\alpha v \beta 3 \text { and } \operatorname{av} \beta 5)\end{array}$ & $\begin{array}{c}\text { Shi et al., 2009; Wickham } \\
\text { et al., } 1993\end{array}$ \\
\hline $\begin{array}{l}\text { Enterovirus/ } \\
\text { Coxsackievirus B }\end{array}$ & IHC, ISH & Cardiomyocytes & CAR / DAF & $\begin{array}{c}\text { Shi et al., 2009; Coyne \& } \\
\text { Bergelson, } 2006\end{array}$ \\
\hline Parvovirus B19 & $\begin{array}{l}\text { ISH, LCM + } \\
\text { PCR }\end{array}$ & $\begin{array}{l}\text { Endothelial cells, } \\
\text { cardiomyocytes }\end{array}$ & $\begin{array}{c}\text { Gb4Cer / } \\
\text { Integrin (a5 } \beta 1) \\
\text { Ku80 autoantigen }\end{array}$ & $\begin{array}{l}\text { Bultmann et al., 2003; } \\
\text { Bönsch et al., } 2010\end{array}$ \\
\hline $\begin{array}{l}\text { Human Herpes } \\
\text { Virus } 6\end{array}$ & $\begin{array}{l}\text { In vitro } \\
\text { Infection }\end{array}$ & Endothelial cells & CD46 & $\begin{array}{l}\text { Caruso et al., 2002; Santoro } \\
\text { et al., } 1999\end{array}$ \\
\hline Cytomegalovirus & ISH & Cardiomyocytes & $\begin{array}{l}\text { Integrins ( } \alpha 2 \beta 1 \text {, } \\
a 6 \beta 1 \text {, and } \alpha v \beta 3 \text { ) }\end{array}$ & $\begin{array}{l}\text { Feire et al., 2004; Kyto et } \\
\text { al., } 2005\end{array}$ \\
\hline $\begin{array}{l}\text { Epstein-Barr } \\
\text { Virus }\end{array}$ & ISH & Lymphocytes B & CD21 & $\begin{array}{l}\text { Chimenti et al., 2004; } \\
\text { Takano et al., } 2008\end{array}$ \\
\hline Influenza Virus & ISH & $\begin{array}{l}\text { Macrophages, } \\
\text { Lymphocytes }\end{array}$ & ND & Cioc et al., 2002 \\
\hline
\end{tabular}

EM indicated electron microscopy; IHC, immunohistochemistry ; ISH, in situ hybridrization; LCM + PCR, polymerase chain reaction using tissue samples isolated with laser capture microdissection; CAR, coxsackie and adenovirus receptor; DAF, decay accelerating factor; $\mathrm{CD}$, cluster of differentiation and ND, not determined

Table. 1. Cardiovascular tissular localization of common cardiotropic viruses and local suspected cellular receptors involved in the process of infection.

At the beginning of human viral infection, the first line of immune defense consists in the innate immune response (NKT cells, monocytes and macrophages). Cell-mediated immunity also plays an important role in viral clearing. Cytotoxic (CD8+) cells recognize degraded viral protein fragments that are presented by major histocompatibility-complex class I antigens on the myocyte surface (Seko et al., 1990) (Figure 1). The Toll-like receptors located at the surface or inside of dendritic cells (more particularly the Toll-like-receptors 4, 7 , and 8 in the case of virus Coxsackie B infection) could recognize certain viral proteins or genomic and then activate intracellular signals (NF-kB pathways) responsible for a fast synthesis and secretion of pro-inflammatory cytokines as interferons and chemokines and also nitric oxide (Ayach et al., 2003; Kawai, 1999; Matsumori et al., 1994) (Figure 1). The proinflammatory cytokines then attract and activate many immune system cell lines to the site of the viral infection and they are directly responsible for cardiac myocytes lysis and also for lost of cardiomyocyte contractility and apoptosis cell-dead (Feldman \& McNamara, 2000; Ventéo et al., 2010) (Figure 1).

\subsection{Sub-acute myocarditis with an activation of the immune system and the development of autoimmunity}

The activation of the immune system at the time of the viral invasion reaches to the initiation of specific cellular immunity response and to the immune shift towards a specific immune response. The viral particles are captured by antigen processing cells (APC) and degraded within the Golgi apparatus before being presented at the cell surface by the major histocompatibility complex class I (MHC class I) to the CD8+ lymphocytes. These primed T 
cells capable to detect the viral antigen will destroy the infected cardiac cells through cytokines or perforines secretion (Kawai, 1999, Matsumori et al., 1994). In addition, some myocardic cellular antigens of the host present can share epitopic similarities (molecular mimicry) with viral antigens therefore inducing an autoimmune trait that can sustain the inflammatory response and therefore the chronic inflammation phases (Figure 1). This subacute phase is known to be linked to autoimmune responses as many patients produce autoantibodies and auto-reactive T cells against heart proteins (Domenico \& Gaetano, 2006; Feldman \& McNamara, 2000) and the amplification of this phenomenon can lead to the destruction of cardiomyocytes. The mechanisms linking enteroviral infection with sub-acute myocarditis, relapses and post inflammatory heart failure could be mainly mediated by dendritic cells (DCs) that are specialized in antigen processing and presentation and most important in priming of $\mathrm{T}$ cells within lymph nodes. The EV-induced autoimmune myocarditis may require activation of these cells via CD40 with Toll like receptors (TLRs 3, $4,7)$ or RNA helicases (RIG-I, MAD-5) co-stimulation (Kramer et al., 2008). Moreover in human infections, it is clear that human enteroviruses (HEVs) can escape from immunological system by decreasing the specific functions of immunity cell system (Oldstone, 2006). Recently it has been demonstrated that Enteroviruses could infect and consequently modify the maturation process and some specialized functions of DCs (Kramer et al., 2007). Therefore, Enteroviruses or some of its components could activate or decrease some DCs functions acting as modulators of innate response system or autoimmunity (Kramer et al., 2007).

\subsection{Chronic myocarditis with a potential evolution to the dilated cardiomyopathy clinical stage}

After the active virus replication resulting in acute and sub acute myocarditis phases, the pathological signs of myocarditis generally disappeared and the destroyed myocytes are replaced by diffuse fibrosis (Dec et al., 1985) (Figure 1). At this stage, a progressive heart biventricular dilatation with a cardiac failure can be observed and has been related to cardiac persistent or chronic viral replication mechanisms (Andréoletti et al., 2000; Badorff et al., 1999) (Figure 1). This persistent or chronic viral infection could be related with various cardiac cell dysfunctions as impairment of $\mathrm{Ca}+$ efflux in cardiomyocytes and of loss of cell contractility, apoptosis balance deregulation, cleavage of dystrophine, modulation of cellular signalling pathways or alteration of the extracellular matrix (Andréoletti et al., 2009; Dennert \& McNamara, 2009; Kawai, 2009; Khül et al., 2008a).

\section{The Virological mechanisms of cardiac infection}

\subsection{Acute viral myocarditis}

Viruses generally infect human beings by fecal-oral (enteroviruses, parvovirus B19, Herpesviruses) or respiratory routes (enteroviruses, influenza viruses $A \mathcal{E} B$, parainfluenza viruses I II III) and they usually perform a first phase of multiplication into the airway epithelial cells of the higher respiratory tract or tonsils; this can be followed by a potential rapid invasion of the lower respiratory tract as observed during influenza virus infection. After this initial and local replication phase, the viruses can diffuse by lymphatic way to the general circulation (viremic phase) allowing them to reach the cardiac tissues. In the heart, the virus infects and replicate actively into the cardiac myocytes but also into the cardiac fibroblasts that can play the role of reservoir cells for a persistent infection (Andréoletti et 
al., 2009). During this active phase of replication, the development of the classical clinical signs of myocarditis is usually observed (Andréoletti et al., 2007; Magnani \& Dec, 2006).

\subsection{The chronic persistent viral Infection in heart tissues \\ 4.2.1 The enterovirus model}

After the acute myocarditis phase, persistence can be observed as described during human cardiac enterovirus (EV) infection. In some previous published studies, detection of viral genome has been demonstrated in patients with myocarditis and in patients with DCM, but it is unusual that replication competent virus can be isolated from the myocardium in patients with myocarditis (Andréoletti et al., 2009; Chapman \& Kim, 2008a; Copper, 2009). The concept that EV endomyocardial persistent infections are the etiological cause of a subset of idiopathic DCM cases is supported by the detection of enterovirus genomic sequences and enteroviral capsid protein VP1 in up to $35 \%$ of explanted heart tissues from end-stage DCM patients (Andreoletti et al. 2009; Li et al., 2000). In a previous published study, we observed that enteroviruses can persist with or without active viral replication in cardiac tissue of patients with end-stage dilated cardiomyopathy (Andréoletti et al., 2000). Enterovirus genome was detected in 25 of 70 patients with IDCM and, of these patients positive for genomic RNA, only 3 exhibited antigenomic RNA and VP1 antigen that demonstrated active viral replication, whereas 22 had latent infection characterized by the absence of antigenomic RNA associated with or not with VP1 antigen expression. No viral component was detected in control subjects (Andréoletti et al., 2000). These findings demonstrated that a small percentage of patients with end-stage chronic cardiac diseases had active enterovirus replication in their myocardium. Moreover, we demonstrated that enteroviral capsid protein VP1 was present in myocardial tissues from some patients with dilated cardiomyopathy and suggested that the pattern of VP1 detection may correlate with disease stage and severity. These data suggested that viral protein synthesis might be involved in persistent enterovirus infection in the pathogenesis of DCM (Li et al., 2000). It was observed that the ratio of positive- to negative-strand enteroviral RNA was greater with active virus replication than with persistent virus infection where a viral capsid protein synthesis activity was also evidenced in heart cardiac tissues (Andréoletti et al., 2000; Li et al., 2000, Chapman \& Kim, 2008a). This slow viral replication could be explained by the existence of $5^{\prime} \mathrm{NC}$ genomic deleted viral forms that could be related to the development of slow replicating viral forms in heart tissues (Chapman et al., 2008b). As persistent expression of CVB proteins and 2Aprotease (2Apro) alone are sufficient for induction of cardiomyopathy in the mouse and as detection of HEV TD genomes in adult human heart disease is likely due to persistent HEV TD genomes, there is now a new hypothetical mechanism to link of acute viral myocarditis with postviral DCM (Chapman et al. 2008b).

\subsubsection{The Parvovirus B19 model}

Concerning the Parvovirus B19 virus, a persistent infection was detected in intra-cardiac endothelial cells of small arterioles and veins of patients with chronic cardiomyopathies by in situ hybridization and PCR techniques. This persistent PVB19 infection associated with a low viral replication may be associated with endothelial dysfunction, impairment of myocardial microcirculation, penetration of inflammatory cells and secondary myocyte necrosis. (Duechting et al., 2008). The molecular mechanisms responsible for the reactivation 
of latent parvovirus B19 infection, the influence of immune activation triggering parvovirus B19 replication and chronic myocarditis, and immune-independent viral pathogenesis remains to be assessed (Bock et al., 2010).

\subsection{The chronic latent viral cardiac infections}

In cases of herpesviruses (HSV1, HSV-2 , HCMV, HHV-6) cardiac infection a latent phase can occur subsequently to the acute phase of infection as demonstrated in a mice model (Grodums \& Zbitnew, 1976). During this HSV experimental latent infection, HSV-DNA can be identified as agents of a persistent heart infection in cardiomyocytes, fibroblasts or Schwann cells, which has be seen in unmyelitinated axons in murine heart tissues. In human subjects, CMVH was detected in cardiomyocytes and in cardiac fibroblasts of patients with histological proven myocarditis (Schönian et al., 1995). Moreover, it was not possible to detect viral mRNA coding for structural proteins known as late proteins but only mRNA coding for viral enzymatic proteins (early proteins) related to the regulation of viral replication or associated with the HCMV DNA replication (Lenzo et al., 2002) Whatever, the cellular sites as well as the mechanisms of latency and reactivation of the herpesviruses (EBV, HCMV and HHV6) in human heart tissues remain to be assessed (Andréoletti et al., 2009; Cooper, 2009; Dennert et al., 2008).

\section{Viral causes for human acute or chronic myocarditis}

Human Enteroviruses, (picornaviridae), specifically Coxsackie group B serotypes, Parvovirus B19, HHV6 of the B type and the adenovirus are the most frequently etiological viral agents implicated in the acute myocarditis of the child or the young adult ( $<35$ year-old) (Andréoletti et al., 2009; Bowles et al., 2003; Feldman \& McNamara, 2000; Kühl et al., 2005b; Magnani \& Dec, 2006) (Table 2). Moreover HHV-1, Adenovirus, myxoviruses and also paramyxoviruses including respiratory syncytial virus (RSV), influenza and parainfluenza strains can also induce an acute infection of cardiac tissue as previously demonstrated in reported acute myocarditis cases developed in immunocompetent patients (Bowles et al., 2003; Dennert et al., 2008). Other viruses as EBV or CMV are also associated with this pathology after heart transplantation. HIV or $\mathrm{HCV}$ can be also etiological agents of myocarditis (Matsumori et al., 2006; Sudano et al., 2006) (Table 2).

Recent data showed that it was possible to detect viruses in $71 \%$ of the cases of acute myocarditis using molecular techniques for the virological analysis of cardiac biopsy samples (Table 2) (Kühl et al., 2003). Co-infections were found in more than $12 \%$ of the cases, generally associating HHV6 and Parvovirus B19. HHV6 seems to be an important cofactor of myocarditis due to Parvovirus B19. HHV6 may enhance the pathogenicity of Parvovirus B19 through alterations of the extracellular matrix and modulation of the expression levels of the PVB19) receptor (P-antigen) on endothelial cells facilitating infections of the coronary vascular endothelium (Table 2) (Kühl et al., 2005a).

Concerning chronic myocarditis, there is no clinical data from transverse or longitudinal studies indicating the incidence of various viral causes of cardiac infection. However, viral persistence in the myocardium was associated with ventricular dysfunction whereas viral genome clearance was related to the hemodynamic improvement (Kühl et al. 2005a, 2005b). As in the cases of acute myocarditis, recent studies showed the interest to test a broad panel of cardiotropic viruses at the DCM stage. Thus, in a case series of 245 patients with clinically suggested DCM, one or more viruses were detected in $67 \%$ of the cases (Table 2) (Kühl et al., 


\begin{tabular}{|c|c|c|c|}
\hline $\begin{array}{c}\text { Human cardiotropic } \\
\text { Viruses }\end{array}$ & $\begin{array}{c}\text { Acute } \\
\text { myocarditis }\end{array}$ & $\begin{array}{c}\text { Dilated } \\
\text { Cardiomyopathy }\end{array}$ & References \\
\hline Human enteroviruses & $14-33 \%$ & $8-35 \%$ & $\begin{array}{l}\text { Li et al. 2000; Andréoletti et } \\
\text { al. 2000, Kühl et al. 2005a, } \\
2005 b\end{array}$ \\
\hline $\begin{array}{l}\text { Parvovirus B19 } \\
\text { (PrvB19) }\end{array}$ & $<1-37 \%$ & $51 \%$ & Kühl et al. 2005a, 2005b \\
\hline $\begin{array}{c}\text { Human Herpes Virus } 6 \\
\text { (HHV6) }\end{array}$ & $11 \%$ & $6-22 \%$ & $\begin{array}{l}\text { Kühl et al. 2005a, 2005b, } \\
\text { Mahrhodt et al.2004 }\end{array}$ \\
\hline Adenovirus & $8.1-23 \%$ & $2-12 \%$ & $\begin{array}{l}\text { Kühl et al. 2005a, 2005b, } \\
\text { Bowles et al. } 2003\end{array}$ \\
\hline $\begin{array}{l}\text { Multiple infections } \\
(60 \% \text { of cases }= \\
\text { PrvB19+HHV6) }\end{array}$ & $12 \%$ & $27 \%$ & Kühl et al. 2005a, 2005b \\
\hline \multicolumn{4}{|l|}{$\begin{array}{c}\text { Rare viral causes in } \\
\text { immunocompetent } \\
\text { patients* (non restrictive } \\
\text { list) }\end{array}$} \\
\hline $\begin{array}{l}\text { Cytomegalovirus } \\
(\mathrm{CMVH})\end{array}$ & $3 \%$ & $0.8 \%$ & Kühl et al. 2005a, 2005b \\
\hline $\begin{array}{c}\text { Epstein Barr Virus } \\
(\mathrm{EBV})\end{array}$ & $<1 \%$ & $2 \%$ & Kühl et al. 2005a, 2005b \\
\hline $\begin{array}{l}\text { Herpes Simplex Virus } \\
\text { (HSV) }\end{array}$ & $<1 \%$ & - & Kühl et al. 2005a, 2005b \\
\hline Influenza viruses & $<1-2 \%$ & - & Kühl et al. 2005a, 2005b \\
\hline Hepatitis C & - & - & - \\
\hline HIV & - & - & - \\
\hline
\end{tabular}

(-) Not determined; * Prevalence determined in cases of solid organ transplantation.

Table. 1. Prevalence of viruses detected by molecular biology-based techniques in cardiac tissue samples taken from patients with acute myocarditis or dilated cardiomyopathy.

2005a). Moreover in these patients, the absence of associated myocardial inflammation suggests that viral persistence can be responsible for a modulation of the immune response, which would be decreased from the beginning of the chronic phase of myocarditis (Kawai, 1999; Yajima \& Knowlton, 2009).

\section{Diagnosis of viral causes of myocarditis}

Many common human viruses can be the etiological cause of acute or chronic myocarditis in children or young adult patients (Andréoletti et al., 2009). Because of the large number and serotypes of human viruses potentially responsible for cardiac infection the clinical interest 
of viral serological assay remains of a limited interest in clinical practice (Mhafoud et al., 2011). A recent European study demonstrated that virus serology has no relevance for the diagnosis of myocardial infection in young adults; this study indicated that comparatively to the molecular analysis of endomyocardial biopsy tissues, the positive predictive value was $25 \%$ and that the negative predictive value was $49 \%$ (Mhafoud et al., 2011).Therefore the etiological diagnosis of viral myocarditis is based on the detection of the viruses or viral components (proteins or genomes) in peripheral blood samples at the time of viremia phase (clinically characterized by fever), but also at the entry and the excretion sites (throat, urine and stool samples), and in heart tissue samples that corresponds to the organ site of viral replication. Therefore, endomyocardial biopsy remains the gold standard for unequivocally establishing the histopathological and virological diagnosis of unexplained cardiomyopathies as acute or chronic myocarditis (Li et al., 2000; Mahrholdt et al., 2004). Its clinical impact on prognosis and treatment largely depends on establishing a rapid and standardized set of diagnostic methods including histopathological and virological analyses of endomyocardial tissue taken by endomyocardial biopsy (Aretz et al., 1987; Mahrholdt et al., 2004).

\subsection{Endomyocardial biopsy (EMB)}

As recommended by the Heart Failure Society of America and the Heart Failure Association of the European Society of Cardiology, the implementation of a right or left ventricular EMB is indicated in the case of acute symptoms of heart failure refractory to standard management, a substantial worsening of ejection fraction despite optimized pharmacological therapy, the development of hemodynamically significant arrhythmias, an heart failure with concurrent rash, fever, or peripheral eosinophilia, an history of collagen vascular disease such as systemic lupus, erythematosus, scleroderma, or polyarteritis nodosum, and a new-onset cardiomyopathy in the presence of known amyloidosis, sarcoidosis, or hemochromatosis when no obvious cause, in particular ischemic, could be established (Mahrholdt et al., 2004). EMB remains the gold standard for unequivocally establishing the diagnosis of unexplained cardiomyopathy Li et al., 2000). However, its sensitivity and its specificity are limited by the often-focal distribution of the specific histological lesions (Baughman, 2006).

Cardiac biopsy samples should be obtained in more than one area of the right ventricular septum and the number of samples should range from 5 to 10 of a volume from 1 to $2 \mathrm{~mm}^{3}$. Five of these samples should be fixed in neutralized $10 \%$ formalin or $10 \%$ PFA; five should be flash-frozen or placed immediately conserved at $-80^{\circ} \mathrm{C}$ to perform further classical or molecular virological techniques (Mahrholdt et al., 2004). Interestingly, it has been recently demonstrated that there were no differences in the number of positive left ventricular-EMB, right ventricular-EMB, or left ventricular- and right ventricular-EMB findings when related to the site of cardiovascular magnetic resonance- based late gadolinium enhancement. Preferential biopsy in regions showing late gadolinium enhancement on cardiovascular magnetic resonance does not increase the number of positive diagnoses of myocarditis. (Yilmaz et al., 2010).

\subsection{Histopathological evaluation of cardiac biopsy samples}

Histological evaluation of cardiac biopsies from patients with clinically suspected myocarditis is routinely done according to the Dallas criteria (Cooper, 2009). Since 
myocarditis is a focal disease, 4 to 5 biopsy samples obtained in more than one area of the right ventricular septum should be analysed for light microscopic examination and immunohistochemical assays (Mahrholdt et al., 2004). For routine light microscopy examination, EMB tissue is embedded in paraffin and serial sections are obtained and stained with hematoxylin, eosin. Masson trichrome or Sirius red can be useful for a better evaluation of the fibrosis (Cooper, 2009). Additional slides have to be performed for subsequent immunohistochemical assays (Aretz et al., 1987; Mahrholdt et al., 2004).

To improve the histological diagnosis, additional immunological evaluation of cardiac tissues is required with immunohistochemical techniques allowing quantification, identification, and differentiation of inflammatory cells (Aretz et al., 1987). Criteria for immunohistological diagnosis in the EMB of inflammatory cardiomyopathy is specified quantitatively as $>14$ infiltrating leukocytes $/ \mathrm{mm}^{2}$, preferably T-lymphocytes or activated Tcells. If foci of T-lymphocytes are present, active myocarditis can be diagnosed due to the nature of the infiltrate even when the critical level of 14 leukocytes $/ \mathrm{mm}^{2}$ is not reached (Aretz et al., 1987). Subsequent biopsies will allow reliable follow-up of the myocarditis with a semi-quantitative evaluation of myocardial inflammation, necrosis and healing. If the levels of inflammation appear unchanged from the most recent previous cardiac biopsies, the term ongoing (or persistent) myocarditis will be used (Cooper, 2009).

Finally in cases of clinically suspected viral myocarditis or unexplained cardiomyopathy, Dallas criteria have to be associated with classical immunohistological assays for the identification of inflammatory cells and also for the detection of viral capsid or early or late antigens in EMBs (Andréoletti et al., 2009).

\subsection{Classical virological analyses of samples taken from patients with myocarditis}

The etiological diagnosis of viral myocarditis, specifically during the acute phase corresponding to the acute viral infection, is based on the detection of the viruses or viral components (proteins or genomes) in heart biopsy tissue samples and additionally to detection of viral genomes in peripheral biological samples as whole blood (viremia), throat (classical entry site of viruses) and urine and stool samples. The direct virological techniques are now based on molecular biology (PCR, RT-PCR) and immunohistochemical assays for EMBs. By comparison, the contribution of viral serological assays to the clinical diagnosis of acute or chronic myocarditis is relatively poor and the serological assays are of interest only for a late and retrospective diagnosis of viral myocarditis (Dennert et al., 2009). However, Hepatitis C and B and HIV serologies should be systematic in a patients suffering from acute or chronic myocarditis (Aretz et al., 1987).

Using classical molecular techniques, the genome of enteroviruses, adenoviruses, human hepatitis viruses or herpesviruses can be detected in 40 to $70 \%$ of the cardiac tissues of patients suffering from an histological-proven acute myocarditis (Table 1) (Badorff et al., 1999; Gravanis \& Sternby, 1991). These molecular techniques must be performed on a pool of several EMBs taken, from different heart tissue areas that should be extracted together in order to optimize the efficiency of viral nucleic acid recovery rates (Mahrholdt et al., 2004). Some specialized laboratories use real-time PCR assays that allow a quantitative approach to estimate viral loads of the majority of cardiotropic viruses. However, no published data exist on the clinical value of real-time PCR viral loads and the determination of clinical thresholds that could be capable to differentiate a viral cardiac replicative infection from a persistent or latent viral endomyocardial infection. Only one published study reported a mean value of 500 copies of PVB19 genome per one microgram of extracted DNA as the 
clinical threshold related to a significant endomyocardial inflammation (Bock et al., 2010) Only the strategy of associated classical RT-PCR and PCR assays or PCR-microarrays for the detection of all the most common cardiotropic viruses can provide an accurate diagnosis of viral myocarditis. However, sampling error in this focal cardiac disease and the frequent late timing of EMB can also hamper the clinical application of these molecular assays after disease onset. Finally, a positive RT-PCR or PCR result can provide an etiological diagnosis and have to be evaluated into the clinical context, whereas negative PCR results do not exclude a viral-related cardiac disease. Moreover, the only use of the molecular techniques cannot distinguish an active from a persistent viral cardiac infection. Therefore during the clinical course of myocarditis, the immunohistochemical detection of enterovirus, adenovirus or parvovirus B19 capsid proteins or herpesviruses late proteins is necessary in order to differentiate a viral cardiac infection with replication activities from a persistent or latent cardiac infection (Matsumori et al, 2006; Sudano et al., 2006). In the present time, the combination of molecular and immunohistochemical assays on cardiac tissue samples provides a reliable diagnostic strategy for a complete diagnosis of a potential viral-induced acute or latent/persistent cardiac infections. The direct detection of viral genomes in association with the immunohistochemical detection of viral capsid or late proteins in cardiac tissues is crucial to characterize the phase of the viral infection (acute or persistent/chronic) and therefore to specifically adapt the therapeutic strategies (Andréoletti et al., 2009; Badorff et al., 1999; Gravanis \& Sternby, 1991; Sudano et al., 2006).

\subsection{Use of new techniques for the virological analyses of heart samples taken from patients with myocarditis or dilated cardiomyopathy}

In the present time, classical real time PCR techniques allow a reliable qualitative detection of viral genomes in cardiac tissues of patients in cases of medical diagnosis of hypokinetic cardiomyopathies (Cooper, 2009) or in series of post mortem or explanted heart tissues (Andréoletti et al., 2000, Dennert et al., 2008; Cooper, 2009). The two critical points remain the number of endomyocardial biopsies (5 to 10) their anatomic origin as well the extraction phase that determine the quality of and the sensitivity of detection of the DNA or RNA viral genomic sequences (Cooper, 2009). The standardization of the extraction phase is now possible by the use of semi-automated or totally automated use of standardized procedure using certified available systems (Renois et al.,2010). A pool of several EMBs taken, from different heart tissue areas have to be extracted together in order to optimize the efficiency of viral nucleic acid recovery rates (Copper, 2009; Dennert et al., 2008). Combination of such automated extraction procedures with monoplex or multiplex classical real time RT PCR techniques can allow an international standardization of the molecular qualitative or quantitative detection of DNA or RNA cardiotropic viruses in human endomyocardial biopsies.

It is now possible to use new multiplex amplification assays followed by a microarray hybridization system allowing a simultaneous of 9 to 12 cardiotropic viruses (herpesviruses or human enteroviruses) in a single analysis. We experienced this system in our laboratory and we observed that multiplex PCR-microarray assay provided a consistently robust qualitative detection of at least 9 viruses in on reaction tube (HSV1, HSV2, CMVH, VZV, HHV6, HHV7, HHV8, enteroviruses species A \& B) (unpublished data). We showed that there was a $100 \%$ concordance for positive virus detection results and that the theoretical limits of detection were as low as 10 genome copies for CVB3 Nancy per microgram of total RNA. Because the system used intergrated a internal extraction and ampliciation control, it 
should be assumed that negative results indicate the absence of targeted viruses (Figure 2). The use of such systems could help to standardize the diagnostic detection of cardiotropic viruses in endomyocardial tissues and can be routinely used for a rapid viral detection and screening; however this system is only qualitative and cannot provide semi-quantitative or quantitative viral load values for each detected virus. Therefore in cases of a positive viral detection in cardiac tissues we currently use a second quantitative approach using standardized classical real time viral quantitative detection assays. The obtained results are standardized in viral genome copies per one ug of extracted DNA (Andréoletti et al., 2009, Bock et al., 2010) (Figure 2).

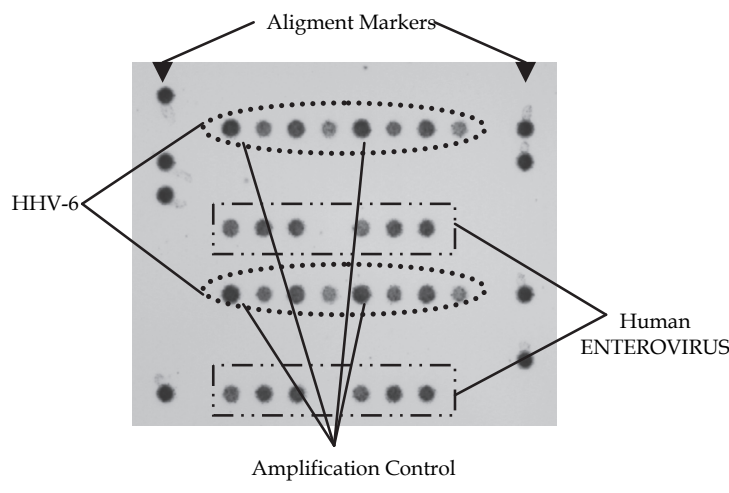

A

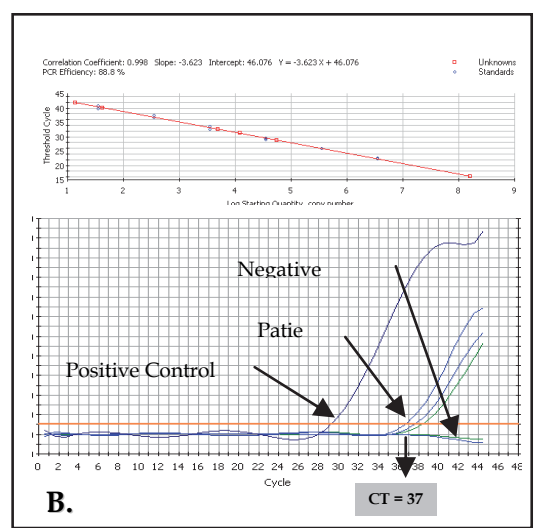

B.

Fig. 2. Detection of a dual Human Enterovirus and HHV6 cardiac infection using a PCRDNA microarray system in an adult patient with an idiopathic dilated cardiomyopathy. A. PCR-DNA microarray system (CLART® Entherpex, Genomica, Madrid, Spain) allowing the detection and typing of 8 Human Herpes viruses and of the Human Enterovirus (HEVs) group. The study patient is co-infected by HHV-6 and Human Enterovirus (Poliovirus, Echovirus or Coxsackievirus).B. Quantitative detection of HEVs in biopsy heart tissues from the same idiopathic DCM patient using classical real time PCR assay and confirming the HEV cardiac infection Amplification curves obtained for positive and negative controls and one HEV positive DCM patient $X$. Positive control corresponded to the CVB3 Nancy strain; Negative control corresponded to healthy heart tissue; CT, cycle threshold.

A new strategy for the molecular detection of cardiac viral infections couples broad-range PCR amplification to electrospray ionization/ mass spectrometry analysis (PCR/ESI-MS). Previous versions of this method were known commercially as the Ibis T5000 and the current commercial hardware platform that conducts the MS analysis is now known as the Abbott PLEX-ID (Ecker et al., 2008). This technique uses primers designed to genomic regions highly conserved regions across viral domains of life. The method was initially developed for the identification of viruses, including previously unknown or unculturable viral agents in samples where multiple microbes may be present, primarily for biodefense applications (Ecker et al., 2008). It is now being developed for diagnosis of human cardiac infections by our team (Figure 3). Preliminary data obtain from 52 heart biopsy samples taken from 24 patients with idiopathic DCM showed a Kappa test correlation of $0.7+/-0.22$ between PleX-ID detection system and 8 monoplex Q rt-PCR assays. Among the 24 study 
patients, our findings indicated that EV (12.5\%), PVB19 (12.5\%) and dual EV-PVB19 (25\%) infections were identified as major potential etiological causes of idiopathic DCM (personal data; not shown). Moreover this new system allowed a rapid semi-quantitative detection of EV associated with a genotyping identification of the EV strains (CVB3 or CVB5; personal data not shown) (Figure 3). Finally this system allows a rapid and valuable quantitative detection and genotyping identification of common viruses in heart tissues and can be used in clinical practice for an accurate diagnostic of viral cardiac infection.

A

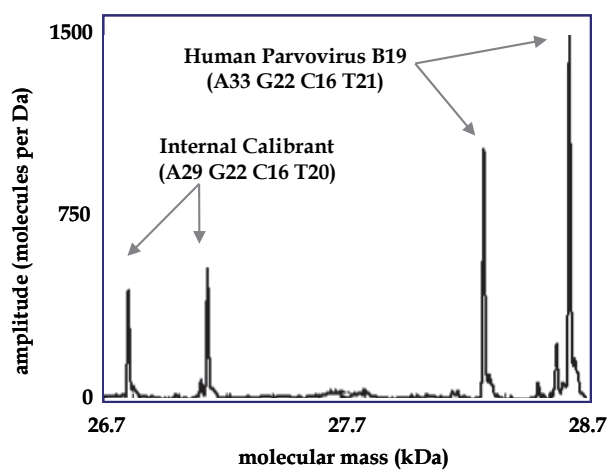

B

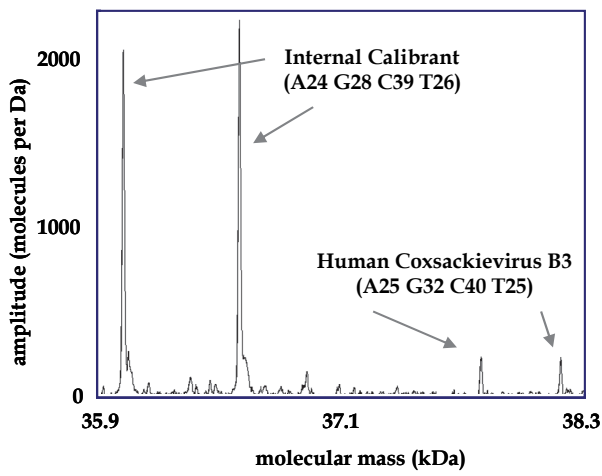

Fig. 3. Detection of parvovirus B19 (panel A) or coxsackievirus B3 (Panel B) in cardiac tissues of two patients (A and B) with idiopathic dilated cardiomyopathy using broadrange PCR amplification followed by ionisation and mass spectrometry analysis (personnal data 2011).

\section{Conclusions and therapeutic perspectives}

To improve histological diagnosis of viral myocarditis, additional virological evaluation of cardiac tissues is required with immunohistochemical and polymerase chain reaction (PCR) techniques allowing identification and quantification of viral infection markers. The diagnostic gold standard is endomyocardial biopsy (EMB) with the histological Dallas criteria, in association with new immunohistochemical and PCR analyses of cardiac tissues. These new viral diagnostic approaches can lead to better identification of the aetiology of myocarditis and can improve the clinical or therapeutic monitoring of viral causes of human myocarditis. Therapeutic strategies adapted specifically to the phase of the disease are currently under evaluation and may improve prognosis and clinical outcomes significantly. It might be more efficient to use positive immunomodulators (interleukins, interferon alpha, interferon gamma) alone or in combination with specific antiviral components such as ribavirin in the initial phase of the disease when viral replication activity can be detected in the cardiomyocytes (Külh et al., 2003). By contrast, immunosuppressive drugs would be more appropriate in the chronic phase of myocarditis, when no or low viral replication activities are detectable in cardiac tissues by immunohistochemistry assays.

Further specific strategies could consist to specifically block the entry of the virus in target cardiac cells, by preventing interaction of viruses with their cellular receptor and their 
consequent signalling amplification systems, such as the tyrosine kinase p56lck, phosphatase CD45 and downstream ERK1/2 (Dennert et al., 2008). Preventing direct viral damage using antiviral therapy is another possible approach by use of specific viral drugs (anti-protease or inhibitors of RNA/DNA polymerases) or by use of general antiviral strategies (interfering RNA). Future randomized placebo-controlled trials should be based upon aetiological diagnosis (viral vs. other causes) and may provide novel treatment options and possibly a better prognosis for these selected patients.

\section{References}

Andréoletti, L., Wattre, P., Decoene, C., Lobert, PE., Dewilde, A., \& Hober, D. (1995). Detection of enterovirus-specific RNA sequences in explanted myocardium biopsy specimens from patients with dilated or ischemic cardiomyopathy. Clin Infect Dis 21:1315-1317.

Andréoletti, L., Hober, D., Becquart, P., Belaich, S., Copin, MC., Lambert, V., \& Wattré, P. (1997). Experimental CVB3-induced chronic myocarditis in two murine strains: evidence of interrelationships between virus replication and myocardial damage in persistent cardiac infection. J Med Virol 52:206-214.

Andréoletti, L., Bourlet, T., Moukassa, D., Rey, L., Hot, D., Li, Y., Lambert, V., Gosselin, B., Mosnier, JF., Stankowiak, C., \& Wattré, P. (2000). Enteroviruses can persist with or without active viral replication in cardiac tissue of patients with end-stage ischemic or dilated cardiomyopathy. J Infect Dis 182:1222-1227.

Andréoletti, L., Ventéo, L., Douche-Aourik, F., Canas, F., Lorin de la Grandmaison, G., Jacques, J., Moret, H., Jovenin, N., Mosnier, JF., Matta, M., Duband, S., Pluot, M., Pozzetto, B., \& Bourlet, T. (2007). Active Coxsackieviral B infection is associated with disruption of dystrophin in endomyocardial tissue of patients who died suddenly of acute myocardial infarction. J Am Coll Cardiol. 50:2207-2214.

Andréoletti, L., Lévêque, N., Boulagnon, C., Brasselet, C., \& Fornes, P. (2009). Viral causes of human myocarditis. Arch Cardiovasc Dis. 102:559-68.

Aretz, HT., Billingham, ME., Edwards, WD., Factor, SM., Fallon, JT., Fenoglio, JJ., Olsen, EG., \& Schoen, FJ. (1987). Myocarditis. With histopathologic definition and classification. Am J Cardiovasc Pathol 1:3-14.

Ayach, B., Fuse, K., Martino, T., \& Liu, P. (2003). Dissecting mechanisms of innate and acquired immunity in myocarditis Curr Opin Cardiol. $18: 175-181$.

Badorff, C., Lee, GH., Lamphear, BJ., Martone, ME., Campbell, KP., Rhoads, RE., Knowlton, KU. (1999). Enteroviral protease 2A cleaves dystrophin: evidence of cytoskeletal disruption in an acquired cardiomyopathy. Nat Med. 5:320-326.

Badorff, C., Zeiher, AM., Hohnloser, SH. (2001). Torsade de pointes tachycardia as a rare manifestation of acute enteroviral myocarditis. Heart 86:489-490.

Baughman, KL. (2006). Diagnosis of myocarditis: death of Dallas criteria. Circulation 113 : 593-595.

Bock, CT., Klingel, K., \& Kandolf, R. (2010). Human parvovirus B19-associated myocarditis. N Engl J Med. 362:1248-9.

Bönsch, C., Zuercher, C., Lieby, P., Kempf, C., Ros, C. (2010). The globoside receptor triggers structural changes in the B19 virus capsid that facilitate virus internalization. J Virol. 84:11737-46. 
Bowles, NE., Ni, J., Kearney, DL., Pauschinger, M., Schultheiss, HP., McCarthy, R., Hare, J., Bricker, JT., Bowles, KR., \& Towbin, JA. (2003). Detection of viruses in myocardial tissues by polymerase chain reaction. evidence of adenovirus as a common cause of myocarditis in children and adults. J Am Coll Cardiol. 42:466-72.

Bültmann, BD., Klingel, K., Sotlar, ., Bock, CT., Baba HA., Sauter, M., \& Kandolf R. (2003). Fatal parvovirus B19-associated myocarditis clinically mimicking ischemic heart disease: an endothelial cell-mediated disease. Hum Pathol. 34:92-5.

Caruso, A., Rotola, A., Comar, M., Favilli, F., Galvan, M., Tosetti, M., Campello, C., Caselli, E., Alessandri, G., Grassi, M., Garrafa, E., Cassai, E., \& Di Luca, D. (2002). HHV-6 infects human aortic and heart microvascular endothelial cells, increasing their ability to secrete proinflammatory chemokines. J Med Virol. 67:528 -533.

Chapman, NM., \& Kim, KS. (2008a). Persistent coxsackievirus infection: enterovirus persistence in chronic myocarditis and dilated cardiomyopathy. Curr Top Microbiol Immunol. 323:275-92.

Chapman, NM., Kim, KS., Drescher, KM., Oka, K., \& Tracy, S. (2008b). 5 ' terminal deletions in the genome of a coxsackievirus B2 strain occurred naturally in human heart. Virology. 375:480-91.

Chimenti, C., Russo, A., Pieroni, M., Calabrese, F., Verardo, R., Thiene, G., Russo, MA., Maseri, A., \& Frustaci, A. (2004). Intramyocyte detection of Epstein-Barr virus genome by laser capture microdissection in patients with inflammatory cardiomyopathy. Circulation. 110:3534 -3539.

Cioc, AM., \& Nuovo, GJ. (2002). Histologic and in situ viral findings in the myocardium in cases of sudden, unexpected death. Mod Pathol. 15:914-922.

Cooper, LT. (2003). Myocarditis: from bench to bedside. Totowa, NJ, Humana Press.

Cooper, LT., Baughman, KL., Feldman, AM., Frustaci, A., Jessup, M., Kuhl, U., Levine, GN., Narula, J., Starling, RC., Towbin, J., \& Virmani, R. (2007). The role of endomyocardial biopsy in the management of cardiovascular disease: a scientific statement from the American Heart Association, the American College of Cardiology, and the European Society of Cardiology. J Am Coll Cardiol. 50:1914-31.

Cooper, LT. (2009). Myocarditis. N Engl J Med 360 : 1526-1538.

Dec, GW., Palacios, IF., Fallon, JT., Aretz, HT., Mills, J., Lee, DC., \& Johnson, RA. (1985). Active myocarditis in the spectrum of acute dilated cardiomyopathies. Clinical features, histologic correlates, and clinical outcome. N Engl J Med. 312:885-90.

Coyne, CB., \& Bergelson, JM. (2006). Virus-induced Abl and Fyn kinase signals permit coxsackievirus entry through epithelial tight junctions. Cell. 124:119-31.

Dennert, R., Crijns, HJ., \& Heymans, S. (2008). Acute viral myocarditis. Eur Heart J 29:20732082.

Domenico, C., \& Gaetano, T. (2006). Arrhythmogenic right ventricular cardiomyopathy / dysplasia: clinical impact of molecular genetic studies. Circulation. 113:1634-1637.

Duechting, A., Tschöpe, C., Kaiser, H., Lamkemeyer, T., Tanaka, N., Aberle, S., Lang, F., Torresi, J., Kandolf, R., \& Bock, CT. (2008). Human parvovirus B19 NS1 protein modulates inflammatory signaling by activation of STAT3/PIAS3 in human endothelial cells. J Virol. 82:7942-52.

Ecker, DJ., Sampath, R., Massire, C., Blyn, LB., Hall, TA., Eshoo, MW., \& Hofstadler, SA. (2008). Ibis T5000: a universal biosensor approach for microbiology. Nat Rev Microbiol. 6:553-8. 
Feire, AL., Koss, H., \& Compton, T. (2004). Cellular integrins function as entry receptors for human cytomegalovirus via a highly conserved disintegrin-like domain. Proc Natl Acad Sci U S A. 101:15470-5.

Feldman, AM., \& McNamara, D. (2000). Myocarditis. N Engl J Med 343:1388-1398.

Gravanis, MB., \& Sternby, NH. (1991). Incidence of myocarditis. A 10-year autopsy study from Malmo, Sweden. Arch Pathol Lab Med. 115:390-392.

Grodums, EI., \& Zbitnew, A. (1976). Experimental herpes simplex virus carditis in mice. Infect Immun. 14:1322-31.

Huber, SA. (1993). Animal models: immunological aspects. In Banatvla JE, ed, Viral Infections in the Heart. London, Edward Arnold, 82-109.

Kawai, C. (1999). From myocarditis to cardiomyopathy: mechanisms of inflammation and cell death: learning from the past for the future. Circulation. $99: 1091-1100$.

Kramer, M., Schulte, BM., Toonen, LW., de Bruijni, MA., Galama, JM., Adema, GJ., van Kuppeveld, FJ. (2007). Echovirus infection causes rapid loss-of-function and cell death in human dendritic cells. Cell Microbiol. 9:1507-18.

Kramer, M., Schulte, BM., Toonen, LW., Barral, PM., Fisher, PB., Lanke, KH., Galama, JM., van Kuppeveld, FJ., \& Adema, GJ. (2008). Phagocytosis of picornavirus-infected cells induces an RNA-dependent antiviral state in human dendritic cells. J Virol. 82:2930-7.

Kühl, U., Noutsias, M., Seeberg, B., \& Schultheiss, HP. (1996). Immunohistological evidence for a chronic intramyocardial inflammatory process in dilated cardiomyopathy. Heart 75:295300.

Kühl U., Pauschinger M., Schwimmbeck P.L., Seeberg, B., Lober, C., Noutsias, M., Poller, W., \& Schultheiss, HP. (2003). Interferon-beta treatment eliminates cardiotropic viruses and improves left ventricular function in patients with myocardial persistence of viral genomes and left ventricular dysfunction. Circulation. 107 : 2793-2798.

Kühl, U., Pauschinger, M., Noutsias, M., Seeberg, B., Bock, T., Lassner, D., Poller, W., Kandolf, R., \& Schultheiss HP. (2005a). High prevalence of viral genomes and multiple viral infections in the myocardium of adults with "idiopathic" left ventricular dysfunction. Circulation. 111:887-893.

Kühl, U., Pauschinger, M., Seeberg, B., Lassner, D., Noutsias, M., Poller, W., \& Schultheiss, HP. (2005b). Viral persistence in the myocardium is associated with progressive cardiac dysfunction. Circulation 112:1965-1970.

Kyto, V., Vuorinen, T., Saukko, P., Lautenschlager, I., Lignitz, E., Saraste, A., \& VoipioPulkki, LM. (2005). Cytomegalovirus infection of the heart is common in patients with fatal myocarditis. Clin Infect Dis. 40:683- 688.

Lee, GH., Badorff, C., \& Knowlton, KU. (2000). Dissociation of sarcoglycans and the dystrophin carboxyl terminus from the sarcolemma in enteroviral cardiomyopathy. Circ Res 87:489-495.

Lenzo, JC., Fairweather, D., Cull, V., Shellam, GR., \& James Lawson, CM. (2002). Characterisation of murine cytomegalovirus myocarditis: cellular infiltration of the heart and virus persistence. J Mol Cell Cardiol. 34:629-40.

Li, Y., Bourlet, T., Andréoletti, L., Mosnier, JF., Peng, T., Yang, Y., Archard, LC., Pozzetto, B., \& Zhang, H. (2000). Enteroviral capsid protein VP1 is present in myocardial tissues from some patients with myocarditis or dilated cardiomyopathy. Circulation 101:231-234. 
Liu, PP., \& Mason, JW. (2001). Advances in the understanding of myocarditis. Circulation. $104: 1076-1082$.

Mahfoud, F., Gärtner, B., Kindermann, M., Ukena, C., Gadomski, K., Klingel, K., Kandolf, R., Böhm, M., \& Kindermann, I. (2011). Virus serology in patients with suspected myocarditis: utility or futility? Eur Heart J. 32:897-903.

Magnani, JW., \& Dec, GW. (2006). Myocarditis: current trends in diagnosis and treatment. Circulation 113:876-890.

Mahrholdt, H., Goedecke, C., Wagner, A., Meinhardt, G., Athanasiadis, A., Vogelsberg, H., Fritz, P., Klingel, K., Kandolf, R., \& Sechtem, U. (2004). Cardiovascular magnetic resonance assessment of human myocarditis: a comparison to histology and molecular pathology. Circulation. 109:1250-8.

Matsumori, A., \& Kawai, C. (1982). An animal model of congestive (dilated) cardiomyopathy: dilatation and hypertrophy of the heart in the chronic stage in DBA/2 mice with myocarditis caused by encephalomyocarditis virus. Circulation 66:355-360.

Matsumori, A., Shimada, T., Chapman, NM., Tracy, SM., \& Mason, JW. (2006). Myocarditis and heart failure associated with hepatitis $C$ virus infection. J Card Fail. 12:293-298.

Matsumori, A., Yamada, T., Suzuki, H., Matoba, Y., \& Sasayama, S. (1994). Increased circulating cytokines in patients with myocarditis and cardiomyopathy. Br Heart J. $72: 561-566$.

Oldstone, MB. (2006). Viral persistence: parameters, mechanisms and future predictions. Virology. 344:111-8.

Renois, F., Talmud, D., Huguenin, A., Moutte, L., Strady, C., Cousson, J., Lévêque, N., \& Andréoletti, L. (2010). Rapid detection of respiratory tract viral infections and coinfections in patients with influenza-like illnesses by use of reverse transcription-PCR DNA microarray systems. J Clin Microbiol. 48:3836-42.

Santoro, F., Kennedy, PE., Locatelli, G., Malnati, MS., Berger, EA., \& Lusso, P. (1999). CD46 is a cellular receptor for human herpesvirus 6. Cell. 99:817-27.

Schönian, U., Crombach, M., Maser, S., \& Maisch, B. (1995). Cytomegalovirus-associated heart muscle disease. Eur Heart J. Suppl O:46-9.

Seko, Y., Tsuchimochi, H., Nakamura, T., Okumura, K., Naito, S., Imataka, K., Fujii, J., Takaku, F., Yazaki, Y. (1990). Expression of major histocompatibility complex class I antigen in murine ventricular myocytes infected with Coxsackievirus B3. Circ Res 67:360-367.

Shi, Y., Chen, C., Lisewski, U., Wrackmeyer, U., Radke, M., Westermann, D., Sauter, M., Tschöpe, C., Poller, W., Klingel, K., \& Gotthardt, M. (2009). Cardiac deletion of the Coxsackievirus-adenovirus receptor abolishes Coxsackievirus B3 infection and prevents myocarditis in vivo. J Am Coll Cardiol. 53:1219-26.

Takano, H., Nakagawa, K., Ishio, N., Daimon, M., Kobayashi, Y., Hiroshima, K., \& Komuro, I. (2008). Active myocarditis in a patient with chronic active Epstein-Barr virus infection. Int J Cardiol. 130:e11- e13.

Sudano, I., Spieker, LE., Noll, G., Corti, R., Weber, R., \& Luscher, TF. (2006). Cardiovascular disease in HIV infection. Am Heart J. 151:1147-1155.

Ventéo, L., Bourlet, T., Renois, F., Douche-Aourik, F., Mosnier, JF., Maison, GL., Pluot, M., Pozzetto, B., \& Andreoletti, L. (2010). Enterovirus-related activation of the cardiomyocyte mitochondrial apoptotic pathway in patients with acute myocarditis. Eur Heart J. 31:728-36. 
Wickham, TJ., Mathias, P., Cheresh, DA., \& Nemerow, GR.(1993). Integrins alpha v beta 3 and alpha $\mathrm{v}$ beta 5 promote adenovirus internalization but not virus attachment. Cell. 73:309-19.

Yajima, T., \& Knowlton, KU. (2009). Viral myocarditis: from the perspective of the virus. Circulation. 119:2615-24.

Yilmaz, A., Kindermann, I., Kindermann, M., Mahfoud, F., Ukena, C., Athanasiadis, A., Hill, S., Mahrholdt, H., Voehringer, M., Schieber, M., Klingel, K., Kandolf, R., Böhm, M., Sechtem, U. (2010). Comparative evaluation of left and right ventricular endomyocardial biopsy: differences in complication rate and diagnostic performance. Circulation. 122:900-9. 


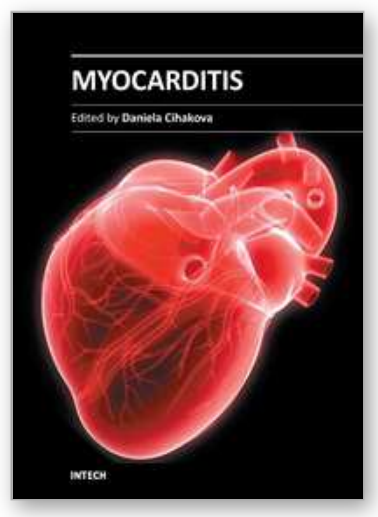

\author{
Myocarditis \\ Edited by Dr. Daniela Cihakova
}

ISBN 978-953-307-289-0

Hard cover, 428 pages

Publisher InTech

Published online 19, October, 2011

Published in print edition October, 2011

Myocarditis, the inflammation of the heart muscle, could be in some cases serious and potentially fatal disease. This book is a comprehensive compilation of studies from leading international experts on various aspects of myocarditis. The first section of the book provides a clinical perspective on the disease. It contains comprehensive reviews of the causes of myocarditis, its classification, diagnosis, and treatment. It also includes reviews of Perimyocarditis; Chagasâ $€^{\mathrm{TM}}$ chronic myocarditis, and myocarditis in HIV-positive patients. The second section of the book focuses on the pathogenesis of myocarditis, discussing pathways and mechanisms activated during viral infection and host immune response during myocarditis. The third, and final, section discusses new findings in the pathogenesis that may lead to new directions for clinical diagnosis, including use of new biomarkers, and new treatments of myocarditis.

\title{
How to reference
}

In order to correctly reference this scholarly work, feel free to copy and paste the following:

Laurent Andréoletti (2011). Viral Myocarditis: Physiopathology and Diagnosis, Myocarditis, Dr. Daniela Cihakova (Ed.), ISBN: 978-953-307-289-0, InTech, Available from:

http://www.intechopen.com/books/myocarditis/viral-myocarditis-physiopathology-and-diagnosis

\section{INTECH}

open science | open minds

\section{InTech Europe}

University Campus STeP Ri

Slavka Krautzeka 83/A

51000 Rijeka, Croatia

Phone: +385 (51) 770447

Fax: +385 (51) 686166

www.intechopen.com

\section{InTech China}

Unit 405, Office Block, Hotel Equatorial Shanghai

No.65, Yan An Road (West), Shanghai, 200040, China

中国上海市延安西路65号上海国际贵都大饭店办公楼 405 单元

Phone: +86-21-62489820

Fax: +86-21-62489821 
(C) 2011 The Author(s). Licensee IntechOpen. This is an open access article distributed under the terms of the Creative Commons Attribution 3.0 License, which permits unrestricted use, distribution, and reproduction in any medium, provided the original work is properly cited. 